\title{
Effect of fungicide farmayod on agrotechnical and technological indicators of grapevine, on viral diseases and oidium
}

\author{
Nadezda Sirotkina ${ }^{1 *}$ \\ ${ }^{1}$ All-Russian Research Institute named after Ya.I. Potapenko for Viticulture and Winemaking - \\ Branch of Federal Rostov Agricultural Research Center, 346421, Novocherkassk, Russia
}

\begin{abstract}
The paper presents the study on the effect of Farmayod's GR (100 g/l of iodine) spraying on vineyards of Cabernet Sauvignon and Baklanovsky varieties on the degree of viral and oidium prevalence as well as on agrobiological and technological indicators. According to the aggregate agrobiological and technological indicators, the best results on Cabernet Sauvignon variety were obtained when the drug was used at a concentration of $0.06 \%$. On the Baklanovsky variety the best indicators were obtained at a drug concentration of $0.04 \%$. Testing of plant samples for the presence of Grapevine fan leaf virus, Arabis mosaic virus and Oidium tuckeri showed that after two years of applying the drug, the prevalence of infected plants (P, \%) with Grapevine fanleaf virus on the Cabernet Sauvignon cultivar varied from 0\% (fungicide concentration 0.04 and $0.05 \%)$ to $0.8 \%(0.06 \%)$ and $2.65 \%$ (control). For Baklanovsky variety: Grapevine fanleaf virus - concentration $0.04 \%$ $1.8 ; 0.05 \%-0.4 ; 0.06 \%-2.0$; control - $2.65 \%$. Arabis mosaic virus - 0 ; $0 ; 3.0 ; 12.1 \%$, respectively. Oidium tuckeri was $0 \%$ in all variants with any drug concentrations. Control variant and later $80 \%$ for 29.09 .
\end{abstract}

\section{Introduction}

The vine (Vitis spp.) is undoubtedly one of the woody crops most widely grown in temperate climates, and a very valuable agricultural commodity. Like most vegetatively propagated crops, vines are attacked by various pests and pathogens, among which infectious intracellular agents (viruses, viroids, prokaryotes limited to phloem and xylem) play a major role, causing heavy losses, reducing the productive life of vineyards and jeopardizing the very survival of affected vines [1].

The fan-leaved vine virus (GFLV) is the oldest and most common viral disease affecting the vine, first documented in 1865 [2]. Synonyms: short-node grapes infectious, degeneration of grapes, infectious degeneration, fan-leaved vine virus. Few nepoviruses infect vines, causing degenerative diseases induced by Grape fanleaf virus (GFLV). The name is derived from the peculiar malformation of infected leaves, which show wide-

*Corresponding author: nad.sirotckina2017@,yandex.ru 
open petiolate sinuses and abnormally collected primary veins, giving the leaf the appearance of an open fan. GFLV and some other nepoviruses that infect the vine can occur in mixed infections [3].

The vine (Vitis spp.) is undoubtedly one of the woody crops most widely grown in temperate climates, and a very valuable agricultural commodity. Like most vegetatively propagated crops, vines are attacked by various pests and pathogens, among which infectious intracellular agents (viruses, viroids, prokaryotes limited to phloem and xylem) play a major role, causing heavy losses, reducing the productive life of vineyards and jeopardizing the very survival of affected vines [3].

The vine is a valuable fruit crop, propagated in a vegetative way, which suffers from a variety of viruses, including some that seriously affect the profitability of vineyards. Currently, 64 viruses belonging to different genera and families have been registered in vines, and new types of viruses are likely to be described in the future. Three viral diseases - grapevine leaf roll, Apple stem pitting virus and infectious degeneration, are of great economic importance worldwide. Viruses associated with these diseases are transmitted by Pseudococcidae, Diaspididae, and Dagger nematodes [4]. Dolya V. V., Meng B., and Martelli G. P. report three families of viruses involved in the most common and economically important diseases of the vine [5]. Group of scientists [6] points out that the analysis of agronomic data allows better understanding of viral diseases.

The symptoms associated with Grapevine fanleaf virus were mentioned many years ago in French, Italian, German, and Austrian literature. The presence of virus sites on vines, with the presence of a nematode - the carrier in local vineyards in the Eastern Mediterranean and Western Asia, shows that the disease could have existed in these areas since the first years of grapevine culture. Together with the vegetatively propagated planting material, Grapevine fanleaf virus and probably the nematode- its carrier spread the disease from Europe to almost all areas of the world where grapevines are now grown: California, Central and South America, South Africa and Australia. The import of grapevine's phylloxera to most European vineyards was an indirect cause of the worldwide spread of Grapevine fanleaf virus, as well as other viral diseases of grapevine. This was facilitated by changes in cultivating methods (grafting on hybrid rootstocks, expanded exchange of planting material and replantings of vineyards, especially in the most famous countries of viticulture) [5].

Nowadays, almost all viticultural countries: Germany [7], Italy [1, 8], the United States [9], China and Japan [10], Turkey [11], Iran [12], and Russia [13, 14, 15], Azerbaijan [16] is also conducting international research [17].

Grapevine fanleaf virus is one of the most serious viral diseases of vines worldwide [7]. The economic impact depends on the tolerance of a variety to the certain viruses. Tolerant varieties produce good yields, while sensitive varieties suffer greatly, showing progressive suppression of bushes, low yield and poor fruit quality, shortened productive period, low ratio of taken scion, reduced rooting of propagated material and reduced resistance to adverse climatic factors [8]. In addition, signs are observed in infected vineyards: short internodes often alternate with longer ones, double nodes are observed, flattened and forked shoots, excessive development of lateral shoots. There is a shedding of flowers and small seedless grape berries are formed.

Many researchers note that control measures of this disease are reduced to prevention: planting certified healthy plants, disinfecting tools between each plant, getting rid of any infectioned plants, checking the soil for GLFV before the start of a season, and using nematode-resistant rootstocks [8, 18]. Viral disease management relies heavily on prevention/exclusion or the use of economic and / or environmental factors [19]. In vitro culture [13] and transgenic plants $[10,19]$ are used to create certified virus-free planting 
material. Despite preventive measures and virus-free planting material, adult vineyards suffer from infections

In the Russian Federation, company NBC Farmbiomed LLC created a medicament based on iodine "Farmayod" GR for the suppression of viral infections in many cultures. Thus, the positive effect of the drug was observed on tomatoes [20], potatoes [21], and apple trees [22]. Radchevskiy P. P. in the Krasnodar region revealed that the use of the drug Farmayod contributes to a more intensive accumulation of sugars in a grape berry juice, accelerates ripening of the crop, improves quality of wine materials [23], as well as shorter periods of root formation of vine cuttings [24].

\section{Materials and methods}

The research object is the reaction of grapevine plants on foliar treatment with the fungicide Farmayod, GY (100 g / 1 of iodine). The research subject was industrial fruit-bearing vineyards of the wine variety Cabernet Sauvignon planted in 2010 and the table variety Baklanovsky planted in 1995. The scheme of experiments in 2015 included three variants for each variety: without treatment (control); Farmayod 0.04 and $0.06 \%$; in 2016-four variants: control; Farmayod 0.04; 0.05 and $0.06 \%$. In 2015, during the growing season, the vineyards were treated three times, in 2016-four times, linking them to the main phases of plant development. Treatment of experimental plants also included autumn and spring washing of bushes during the dormant period at a concentration of $0.1 \%$. The experiments were repeated three times. Statistical analysis was performed with the help of computer program "Statistics". Agrobiological and technological indicators were determined using the method of agrotechnical research [25], and the identification of pathogens was carried out by the method of enzyme immunoassay (ELISA).

\section{Results and Discussion}

In 2015, the spraying was made according to the scheme: first treatment - washing during dormant period with $0.1 \%$ solution; the second - before flowering; and the third - in the phase of small berry; the fourth - in the phase of early ripening of berries with 0,04 and $0,06 \%$ solution; the fifth - in the dormant period at a concentration of $0.1 \%$.

Since the treatment was carried out for the first time this year, it did not affect the fruitfulness of the shoots, because the inflorescences had been formed in May-June of the previous year. In the experiment vineyard of wine variety Cabernet Sauvignon, cultivated with winter covering, a small difference in the number of bunches per 1 bush (44 in the second and 42 in the third) (table 1) was compensated by a larger average mass of bunches in the third variant ( $88 \mathrm{vs} .84 \mathrm{~g}$ ), so the yield of plantings $(8.21 \mathrm{t} / \mathrm{ha}$ ) in these variants was the same. In the control variant, the yield was $7.09 \mathrm{t} /$ ha due to the low average weight of the bunch. The quality indicators of berry juice were approximately equal in the variants with fungicide treatment, and in the control plants indicators were lower - by 20 и 22 $\mathrm{g} / \mathrm{dm}^{3}$.

In the vineyards without winter covering of Baklanovsky variety, as a result of adverse weather conditions (winter 2014-2015), the central buds of wintering eyes were lost. Plant's recovery was held by replacing, base and dormant buds, which are practically infertile. One of the signs of infection of plants with Grapevine fanleaf virus is inhibition of growth and development of shoots. Based on this, we evaluated the effect of the drug by the volume of growth of annual shoots. The data in table 2 indicate a positive effect of the drug on the amount of annual growth and the degree of its maturation. 
Table 1.Yield and quality of Cabernet Sauvignon grapes, 2015.

\begin{tabular}{|c|c|c|c|c|c|c|c|}
\hline \multirow[b]{2}{*}{ No } & \multirow[b]{2}{*}{ Variant } & \multirow[b]{2}{*}{$\begin{array}{c}\text { Cluster } \\
\text { number, } \\
\text { pcs / bush }\end{array}$} & \multirow[b]{2}{*}{$\begin{array}{c}\text { Bunch } \\
\text { average } \\
\text { weight, } g\end{array}$} & \multicolumn{2}{|c|}{ Yield } & \multicolumn{2}{|c|}{$\begin{array}{l}\text { Mass concentration, } \mathbf{g} / \\
\mathbf{d m}^{3 .}\end{array}$} \\
\hline & & & & $\begin{array}{c}\text { bush, } \\
\text { kg }\end{array}$ & t/ha & sugar & $\begin{array}{l}\text { titratable } \\
\text { acids }\end{array}$ \\
\hline 1 & Control & 42 & 76 & 3.2 & 7.09 & 232 & 6.4 \\
\hline 2 & Farmayod $0.04 \%$ & 44 & 84 & 3.7 & 8.21 & 254 & 5.4 \\
\hline 3 & Farmayod $0.06 \%$ & 42 & 88 & 3.7 & 8.21 & 252 & 5.8 \\
\hline & $\mathrm{LSD}_{05}$ & & 5.02 & & 0.45 & 4.0 & \\
\hline
\end{tabular}

Table 2. Indicators of annual growth of shoots of Baklanovsky variety, 2015.

\begin{tabular}{|c|c|c|c|c|c|c|}
\hline No & Variant & $\begin{array}{l}\text { Shoot } \\
\text { load, } \\
\text { pes / } \\
\text { bush }\end{array}$ & $\begin{array}{c}\text { Average } \\
\text { length, sm }\end{array}$ & $\begin{array}{c}\text { Average } \\
\text { diameter, } \\
\text { sm }\end{array}$ & $\begin{array}{c}\text { Volume } \\
\text { of } 1 \text { shoot, } \mathrm{sm}^{3}\end{array}$ & $\begin{array}{c}\text { Maturation, } \\
\%\end{array}$ \\
\hline 1 & Control & 18 & 107 & 0.69 & 39.99 & 60 \\
\hline 2 & $\begin{array}{l}\text { Farmayod } \\
0.04 \% \\
\end{array}$ & 17 & 136 & 0.72 & 55.34 & 72 \\
\hline 3 & $\begin{array}{l}\text { Farmayod } \\
0.06 \%\end{array}$ & 18 & 121 & 0.75 & 53.43 & 74 \\
\hline & $\mathrm{LSD}_{05}$ & & & & 3.88 & 5.29 \\
\hline
\end{tabular}

Thus in the variant with concentration of drug $0.04 \%$, the length of the shoot was longer, but diameter was smaller than in the variant with a concentration of $0.06 \%$. As a result, the volume of shoots was approximately equal, with an approximately equal proportion of maturation. In control plants, all indicators of growth and maturation of shoots were significantly lower.

In 2016, it was decided to expand experiments on the concentrations of Farmayod GR and the number of treatments. The first treatment - washing during the dormant period with $0.1 \%$ solution; the second - spraying before flowering $(0.04 ; 0.05$ and $0.06 \%$ ); the third after flowering; the fourth - in small berry phase; the fifth - in the phase of the beginning of berry maturation; autumn washing during physiological dormant period with $0.1 \%$ solution. For both varieties, variant 3 with the highest concentration of the drug $(0.06 \%)$ in 2015 was the control (without treatment), since two concentration options were studied.

According to table 3, we can conclude that the drug has a positive effect on the parameters of fruitfulness of shoots, as well as on quantity and quality of the crop of Cabernet Sauvignon (fig. 1). According to the proportion of fruit-bearing shoots (76\%), the average bunch weight (112 g), yield (6.7 t/ha) and accumulation of sugars in berry juice $\left(227 \mathrm{~g} / \mathrm{dm}^{3}\right)$, a variant with a treatment at concentration of $0.05 \%$ was the best. Therefore, we can conclude that two-year treatment gives more significant results.

According to the prevalence of infection ( $\mathrm{P}, \%$ ) of Grapevine fanleaf virus on Cabernet Sauvignon variety in the second year of drug use, the following data were obtained (table 4): the viral prevalence in the control variant was $2.65 \%$, and in the fourth variant (plants were not treated in 2015) $-0.8 \%$. Thus, two-year treatment completely frees the plants of this variety from infection. 
Table 3. Load, fruitfulness, yield and quality of Cabernet Sauvignon, 2016.

\begin{tabular}{|c|c|c|c|c|c|c|c|c|c|}
\hline \multirow{2}{*}{ No } & \multirow{2}{*}{ Variant } & \multicolumn{3}{|c|}{ Load, pes/bush } & \multirow[t]{2}{*}{ 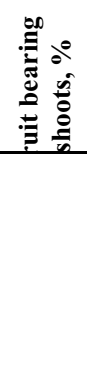 } & \multirow[t]{2}{*}{$\begin{array}{c}\text { Average } \\
\text { bunch } \\
\text { weight, } g\end{array}$} & \multirow[t]{2}{*}{ 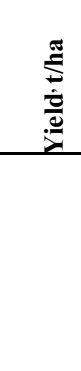 } & \multicolumn{2}{|c|}{$\begin{array}{c}\text { Mass } \\
\text { concentration in } \\
\text { berry juice, } \\
\mathbf{g} / \mathbf{d m}^{3}\end{array}$} \\
\hline & & $\begin{array}{l}\frac{n}{0} \\
\frac{0}{n}\end{array}$ & 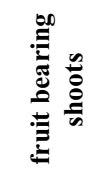 & 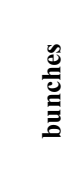 & & & & 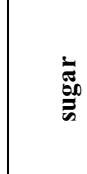 & 语 \\
\hline 1 & Control & 23 & 16 & 23 & 69 & 88 & 4.5 & 208 & 8.9 \\
\hline 2 & $0.04 \%$ & 23 & 17 & 24 & 71 & 103 & 5.5 & 222 & 8.1 \\
\hline 3 & $0.05 \%$ & 25 & 19 & 27 & 76 & 112 & 6.7 & 227 & 8.0 \\
\hline 4 & $0.06 \%$ & 22 & 15 & 23 & 68 & 101 & 5.8 & 220 & 8.2 \\
\hline \multicolumn{2}{|c|}{$\overline{\mathrm{LSD}_{05}}$} & & & & & 5.4 & 0.9 & 5.1 & \\
\hline
\end{tabular}

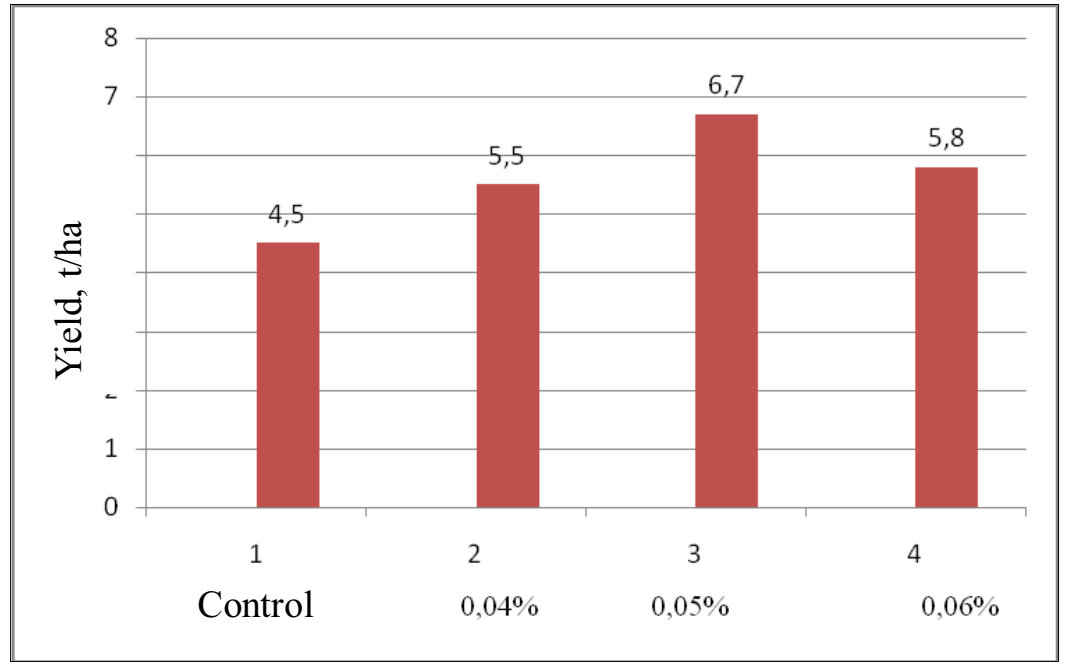

Fig. 1. Yield indicators of Cabernet Sauvignon vineyards.

Table 4. Prevalence of Grapevine fanleaf virus' symptoms on the bushes of Cabernet Sauvignon grapevine under the influence of treatment with fungicide in 2016.

\begin{tabular}{|c|l|c|c|c|c|}
\hline \multirow{2}{*}{ No } & \multirow{2}{*}{ Variant } & \multicolumn{4}{c|}{ Grapevine fanleaf virus } \\
\cline { 3 - 6 } & & \multicolumn{2}{c|}{$\mathbf{0 1 . 0 7 . 1 6}$} & \multicolumn{2}{c|}{$\mathbf{2 9 . 0 9 . 1 6}$} \\
\cline { 3 - 6 } & & $\mathbf{P , \%}$ & $\begin{array}{c}\text { Biological } \\
\text { effectiveness (BE), } \\
\text { \% }\end{array}$ & P, \% & \multirow{2}{*}{ BE, \% } \\
\hline 1 & Control & 2.65 & & 2.65 & 100 \\
\hline 2 & Farmayod $0.04 \%$ & 0 & 100 & 0 & 100 \\
\hline 3 & Farmayod $0.05 \%$ & 0 & 100 & 0 & 70 \\
\hline 4 & Farmayod $0.06 \%$ & 0.8 & 70 & 0.8 & \\
\hline
\end{tabular}


Table 5. Load, fruitfulness and yield of Baklanovsky variety, 2016.

\begin{tabular}{|c|c|c|c|c|c|c|c|c|c|}
\hline \multirow[t]{2}{*}{ No } & \multirow[t]{2}{*}{ Variant } & \multicolumn{3}{|c|}{ Load, pes/bush } & \multirow[t]{2}{*}{ 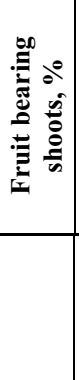 } & \multirow[t]{2}{*}{ 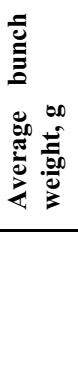 } & \multirow[t]{2}{*}{ 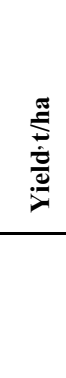 } & \multicolumn{2}{|c|}{ 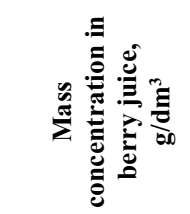 } \\
\hline & & $\begin{array}{l}n \\
\frac{0}{n} \\
\frac{0}{n}\end{array}$ & 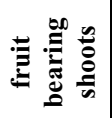 & 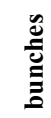 & & & & sugar & $\begin{array}{c}\text { titrat } \\
\text { able } \\
\text { acids }\end{array}$ \\
\hline 1 & Control & 20 & 9 & 12 & 45 & 389 & 10.4 & 153 & 6.9 \\
\hline 2 & Farmayod $0.04 \%$ & 22 & 13 & 17 & 58 & 450 & 17.0 & 172 & 5.7 \\
\hline 3 & Farmayod $0.05 \%$ & 23 & 12 & 15 & 51 & 445 & 14.8 & 176 & 5.2 \\
\hline 4 & Farmayod $0.06 \%$ & 24 & 12 & 15 & 50 & 462 & 15.4 & 177 & 5.5 \\
\hline & $\mathrm{LSD}_{05}$ & & & & & 9.4 & 2.55 & 6.46 & \\
\hline
\end{tabular}

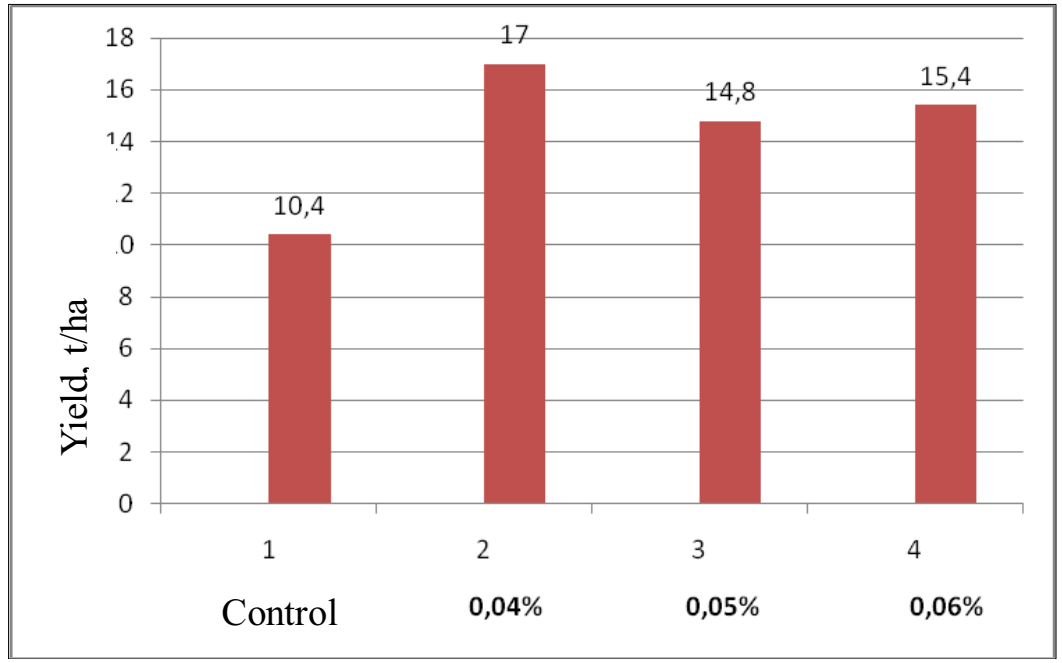

Fig. 2. Yield indicators of Baklanovskiy vineyards.

Formation of small seedless grape berries was not observed in experimental vineyards, but in the control variant had such berries, that affected the average weight of a bunch and yield.

The figures show a shoot and a bunch with signs of Grapevine fanleaf virus - forks (double nodes) and peas of berries in a bunch (Fig. 3) and leaves with signs of Arabis mosaic virus (Fig. 4) on Baklanovsky table grapes. 


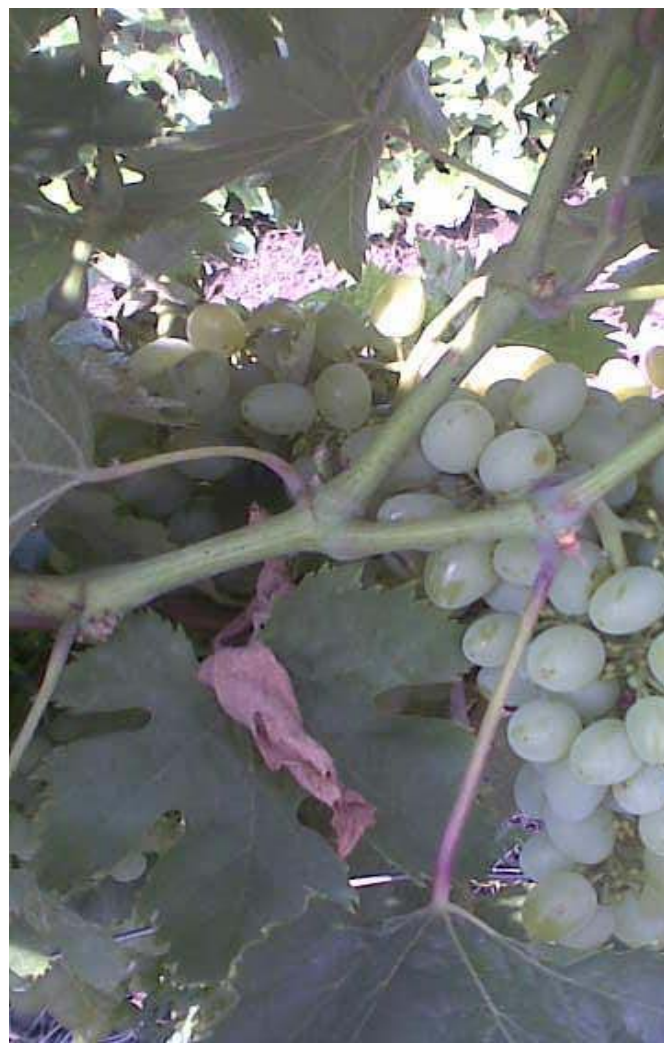

Fig. 3. Signs of Grapevine fanleaf virus on grapes Baklanovsky cultivars

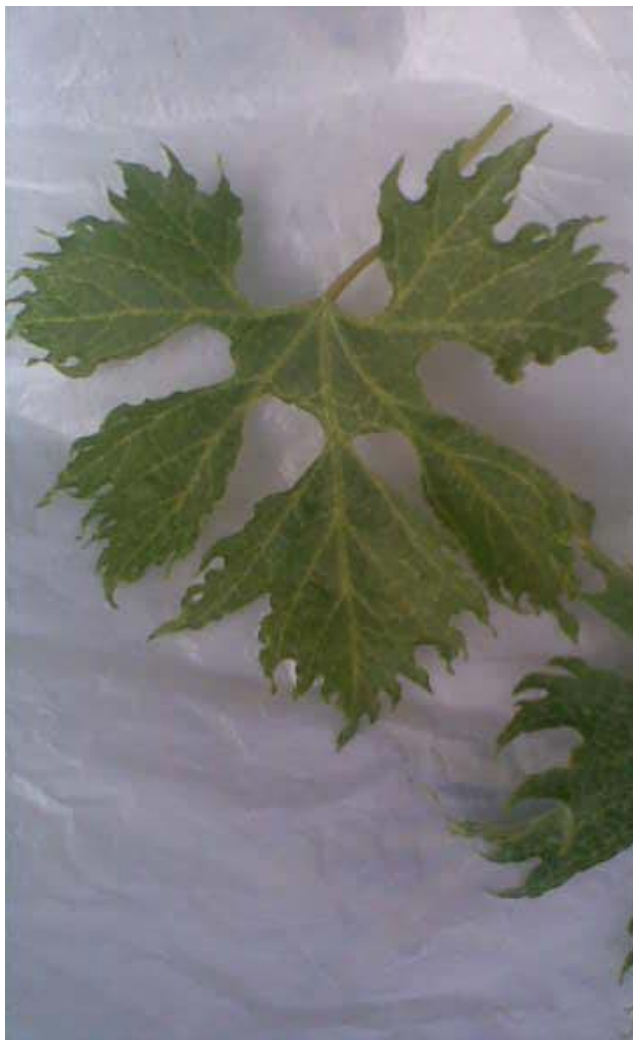

Fig. 4. Leaves of Baklanovsky grape variety with signs of Arabis mosaic virus

Table 6. Prevalence of viral diseases and oidium symptoms on Baklanovsky variety under the influence of treatment with the fungicide Farmayod, GY (100 g / 1 of iodine) 2016.

\begin{tabular}{|c|c|c|c|c|c|}
\hline \multirow{2}{*}{ No } & \multirow{2}{*}{ Variant } & \multicolumn{2}{|c|}{01.07 .16} & \multicolumn{2}{|c|}{29.09 .16} \\
\hline & & $\mathbf{P}, \%$ & BE, $\%$ & $P, \%$ & BE, \% \\
\hline \multicolumn{6}{|c|}{ Grapevine fanleaf virus } \\
\hline 1 & Control & 6,0 & - & 6.0 & - \\
\hline 2 & Farmayod $0,04 \%$ & 1.8 & 70.0 & 1.8 & 70.0 \\
\hline 3 & Farmayod $0,05 \%$ & 0.4 & 93.3 & 0.4 & 93.3 \\
\hline 4 & Farmayod $0,06 \%$ & 2.0 & 66.7 & 2.0 & 66.7 \\
\hline \multicolumn{6}{|c|}{ Arabis mosaic virus } \\
\hline 1 & Control & 12.1 & - & 12.1 & - \\
\hline 2 & Farmayod $0,04 \%$ & 0 & 100 & 0 & 100 \\
\hline 3 & Farmayod $0,05 \%$ & 0 & 100 & 0 & 100 \\
\hline 4 & Farmayod $0,06 \%$ & 3.0 & 75 & 3.0 & 75 \\
\hline \multicolumn{6}{|c|}{ Oidium tuckeri } \\
\hline 1 & Control & 15 & & 80 & \\
\hline 2 & Farmayod $0,04 \%$ & 0 & 100 & 0 & 100 \\
\hline 3 & Farmayod $0,05 \%$ & 0 & 100 & 0 & 100 \\
\hline 4 & Farmayod $0,06 \%$ & 0 & 100 & 0 & 100 \\
\hline
\end{tabular}


Analysis of plant samples of Baklanovskiy variety revealed the least presence of Grapevine fanleaf virus symptoms in the variant with drug concentration $0,05 \%-0,4 \%$ and the largest number of symptoms $(6,0 \%)$ in the control variant (tab. 6). Lower biological effectiveness of fungicide on this variety compared to the Cabernet Sauvignon can be attributed to differences in vineyard age and initial degree of plants contamination.

The drug was more effective against the Arabis mosaic virus. Control variant had $12.1 \%$ of infected plants. After two year treatment with Farmayod, there were no any symptoms, and after one - year treatment the quantity of infected plants decreased for more than 4 times.

Even more effective, the fungicide was against the most dangerous and economically significant fungal diseases - Oidium tuckeri. Even after one-year treatment (variant 3) the plants had no the pathogen, so it is biologically effective for one hundred percent.

\section{Conclusions}

Spraying of grapevine plants with fungicide Farmayod GR revealed:

- $\quad$ on vineyards of Baklanovsky grapevine variety, the shoot volume (by $15.33 \mathrm{sm}^{3}$ ) and the degree of its maturation (by 14\%) in experimental variants were higher than in the control one;

- fruitfulness of shoots increased in the vineyard of Cabernet Sauvignon by $7 \%$, in the vineyard of Baklanovsky - by $13 \%$;

- the average weight of a bunch on Cabernet Sauvignon variety plants increased by 24, on Baklanovsky variety plants - by $73 \mathrm{~g}$;

- the yield in the vineyards of Cabernet Sauvignon variety increased by $2.2 \mathrm{t} / \mathrm{ha}$, in the vineyards of Baklanovsky variety by $6.6 \mathrm{t} / \mathrm{ha}$;

- the mass concentration of sugars in a berry juice of Cabernet Sauvignon increased by $19 \mathrm{~g} / \mathrm{dm}^{3}$, titrated acids decreased by $0.9 \mathrm{~g} / \mathrm{dm}^{3}$; a berry juice of Baklanovsky variety by $24 \mathrm{~g} / \mathrm{dm}^{3}$ and $1.7 \mathrm{~g} / \mathrm{dm}^{3}$, respectively;

- the biological effectiveness of the drug in the vineyards of Cabernet Sauvignon against Grapevine fanleaf virus was $100 \%$; in the vineyards of Baklanovsky variety against Grapevine fanleaf virus 93.3\%, Arabis mosaic virus $100 \%$, Oidium tuckeri $100 \%$.

\section{References}

1. G.P. Martelli, Grapevine Virology: A historical account with an eye to the studies of the last 60 years or so. In Proceedings 18th ICVG meeting, Ankara, Turkey, 16-22, (2015)

2. J.R. Thompson, N. Kamath, K.L. Evolution analysis of the viruses Secoviridae. PLoS ONE 9(9): e106305. https://doi.org/10.1371/journal.pone.0106305 (2014)

3. Authors of Wikipedia, Grapevine fanleaf virus', Wikipedia, The Free Encyclopedia, 02: 57 UTC, (2020) https://en.wikipedia.org/w/index. php?title=Grapevine_fanleaf_virus\&oldid=954941636>

4. Varvara I. Maliogka, Giovanni P. Martelli, Marc Fuchs, Nikolaos I. Katis, Chapter Six - Control of Viruses Infecting Grapevine, Editor(s): Gad Loebenstein, Nikolaos I. Katis, Advances in Virus Research, Academic Press, 91, Pages 175-227 (2015), ISBN 9780128027622, https://doi.org/10.1016/bs.aivir.2014.11.002.

5. V.V. Dolya., B. Meng, G.P. Martelly, Evolutionary aspects of vine Virology. In: Meng B., Martelli G., Golino D., Fuchs M. (eds) Grapevine Viruses: Molecular Biology, 
Diagnostics and Management. Springer (2017) https://doi.org/10.1007/978-3-31957706-7_32.

6. L. Martínez, C. Miranda, J.B. Royo, et al., Scientia Horticulturae , 212, Pages 20-28, (2016) https://doi.org/10.1016/j.scienta.2016.09.023.

7. A.B. Ruiz-Garcí., A. Okic, S.N. Zarghani, et all., First report of a grapevine virus in a grapevine in Germany. plant disease, 102, 1675-1675 (2018)

8. G.P. Martelli Journal of Plant Pathology, 96 (1), 11-27 (2014) DOI: 10.4454 / jpp. V 96ilsup. 3137

9. M. Fuchs, Plant Resistance to Viruses: Engineered Resistance 25 , Reference Module in Life Sciences, Elsevier, 2020, ISBN 9780128096338, https://doi.org/10.1016/B978-012-809633-8.21310-1.

10. X. Fan, M. Zhang, Z. Zhang, et al., Journal of Integrative Agriculture, 19 (3), 768-774 (2020) https://doi.org/10.1016/S2095-3119(19)62677-8

11. G. Tarla, M.A. Yilmaz. Journal of Basic and Applied Sciences, Turkey, 11, 343-347 (2015)

12. S. Nourinejhad-Zarghan, M. Hajizadeh, RRBS, NematSokhandan Bashir, Iran, 10(7), 267-277 (2015)

13. N.P. Doroshenko, Magarach. Viticulture and winemaking, 3, 49-52 (2015)

14. E. Porotikova, U. Dmitrenko and V. Volodinet First Report of Grapevine virus A in Russian. Grapevine Plant Disease, 100 (12), 2541 (2016) http://dx.doi.org/10.1094/PDIS-06-16-0804-PDN.

15. V.I. Risovannaya, S.M. Gorislavec, Evaluation of varietal purity and testing for molecular markers of the major viral infections for producing planting material of grapes SSI Scientific Research of NCRRIH \& V breeding, 11, 165-169 (2016)

16. N. Sultanova, N. Bayramova, D. Aliyeva, et al., Induced changes in metabolic constituents of grapevine (Vitisvinifera L.) leaves infected with grapevine leafrollassociated virus-3 Physiological and Molecular Plant Pathology, 106, 57-63 (2019) https://doi.org/10.1016/j.pmpp.2018.12.005

17. A. Hadidi, G. Vidalakis, T. Sano, et al., Academic Press, 15-25 (2017) ISBN 9780128014981, https://doi.org/10.1016/B978-0-12-801498-1.00002-4.

18. T.S.Pedro, R. Peiró, J.Villanova, et al., Electronic Journal of Biotechnology, 27, 80-83 (2017) https://doi.org/10.1016/j.ejbt.2017.03.006.

19. J .E.Oliver, M. Fuchs, American Journal of Oenology and Viticulture, 62 (4), 438-451 (2011) DOI: 10.5344 / ajev.2011.11036. 39.3 Cornell University.

20. M.A. Keldis, N. Chang, O.N. Chervyakova, Gavrish, 6,16-18 (2013)

21. V.A. Shlyahov, Grigoryan L.N. Bulletin of the Altai State Agrarian University, 7 (153), 52-58 (2017)

22. I.P. Borisova, Prihodko U.N., Podgornaya M.I. Horticulture and viticulture, (3), 52-56 (2019) https://doi.org/10.31676/0235-2591-2019-3-52-56

23. P.P. Radchevskiy, S.S. Basoyan, A. Chich, The nature of changes in agrobiological and technological indicators of Viorica grapes under the influence of Farmayod treatment of plantings. Publishing house: Kuban state agrarian University named after I. T. Trubilin (Krasnodar) eISSN: 1990-4665, 140, 73-99 (2018) DOI: 10.21515/19904665-140-023

24. P.P. Radchevskiy, Viticulture and winemaking, 20 (105), 39-41 (2018)

25. Agrotechnical research on the creation of intensive grapevine plantations on an industrial basis. Novocherkassk, 173 